\title{
Pengembangan Media Belajar Audiovisual Untuk Pembelajaran Memperbaiki Motor Listrik di SMK Negeri 1 Sarolangun
}

\author{
Imam Khomsun $^{1}$ \\ ${ }^{1}$ SMK Negeri 13 Kabupaten Sarolangun, Indonesia \\ Correspondance email: imamsmk13srl@gmail.com
}

\begin{abstract}
Abstrak. Proses pembelajaran untuk kompetensi memperbaiki motor listrik pada kompetensi keahlian Teknik Instalasi Tenaga Listrik SMK Negeri 1 Sarolangun belum berjalan dengan efektif. Pelaksanaan pembelajaran ini hanya menggunakan modul sebagai satu-satunya bahan ajar dan media pembelajaran yang ada. Sementara untuk mendapatkan kompetensi yang diinginkan proses pembelajaran harus ditunjang dengan sarana pembelajaran yang memadai. Menjawab persoalan tersebut, guru sebagai fasilitator dalam pencapaian kompetensi siswa dituntut untuk kreatif mengelola pembelajaran. Salah satunya adalah dengan mencari alternative pemecahan diantaranya dengan mengembangkan media audiovisual untuk pembelajaran memperbaiki motor listrik yang mampu memberikan solusi dalam proses pembelajaran. Pengembangan media ini bertujuan untuk menghasilkan media yang efektif dalam pembelajaran materi memperbaiki motor listrik di SMK Negeri 1 Sarolangun. Model pengembangan yang dipilih adalah berdasarkan pada model Borg dan Gall yang mengadopsi model design pembelajaran Dick dan Carey. Proses pengembangan dilakukan dengan lima langkah utama yaitu: (1) Melakukan Analisis, (2) Merancang produk awal, (3) Validasi dan revisi, (4) Uji coba lapangan sekala kecil, dan (5) Uji coba lapangan kelompok besar. Berdasarkan hasil uji coba lapangan media audiovisual untuk pembelajaran memperbaiki motor listrik di SMK ini, responden dalam uji coba produk memberikan saran agar media tersebut dapat dimanfaatkan dalam proses pembelajaran di sekolah. Alasannya adalah, media ini dapat memberikan informasi dengan jelas langkah-langkah pekerjaan pada materi memperbaiki motor listrik sehingga memberi kemudahan dalam pembelajaran. Kemudahan ini dibuktikan dengan hasil uji coba kelompok besar yang memberikan kesimpulan adanya peningkatan hasil belajar. Dengan demikian media dapat mempercepat pemahaman materi pelajaran.
\end{abstract}

Kata kunci: Pengembangan, Media Audiovisual, Memperbaiki Motor Listrik

\begin{abstract}
Learning process for repairing electricity motor competency at skill competency of Installation Electric Power Technique at SMK Negeri 1 Sarolangun has not been run effectively. In fact, learning material in repairing electricity motor just used modul as teaching materi and media learning. While, to get the competency thad needed, learning process should be supported by leaning tool well. For answer the problem above, teacher as a fasilitator in achievment of students competency is demanded to creative in learning management. One of them is by finding alternative solution that is by develop audiovisual media for learning of repairing electricity motor that can give solution in lerning process. Development of this media aim to product efective media in learning material of repairing electricity motor at SMK Negeri 1 Sarolangun. Development model that chosen is based on Borg and Gall model that adapted lerning design Dick and Carey model. Development process is done by 5 main steps: (1) Doing analysis, (2) Design pre product, (3) Validation and revision, (4) Try out at small scale field and, (5) Try out big group field. Based on the try out of audiovisual media for learning of repairing electricity motor at the SMK, responden give suggestion that the media can be benefit in learning process at school. The reason is that media can give information about the jobs steps clearly at matery of repairing electricity motor so give ease in learning. This ease in proved by the result of try out at big group that give conclution, there is increasingly at the result of study. There by, the media can comprehand learning material fast.
\end{abstract}

Keywords: Development, Audiovisual Media, Repairing Electricity Motor

\section{PENDAHULUAN}

Pendidikan harus mampu mengembangkan potensi peserta didik sehingga yang bersangkutan mampu menghadapi dan memecahkan problem kehidupan yang dihadapinya. Dengan demikian proses pembelajaran di sekolah harus menyentuh potensi nurani maupun potensi kompetensi peserta didik. Konsep pendidikan tersebut terasa semakin penting ketika seseorang harus memasuki kehidupan di masyarakat dan dunia kerja karena yang bersangkutan harus mampu menerapkan apa yang dipelajari di sekolah untuk mengatasi problema yang dihadapi dalam kehidupan sehari-hari saat ini maupun masa yang akan datang. (Sidi, 2004)

Sekolah menengah kejuruan (SMK) sebagai bentuk satuan pendidikan kejuruan sebagaimana ditegaskan dalam penjelasan Pasal 15 UU Sisdiknas, merupakan pendidikan menengah yang mempersiapkan peserta didik terutama untuk bekerja dalam bidang tertentu. Pendidikan Menengah Kejuruan memiliki peran untuk menyiapkan peserta didik agar siap bekerja, baik bekerja secara mandiri (wiraswasta) maupun mengisi lowongan pekerjaan yang ada. Oleh karena itu, arah pengembangan pendidikan menengah kejuruan diorientasikan pada pemenuhan permintaan pasar kerja. 
SMK sebagai salah satu institusi yang menyiapkan tenaga kerja, dituntut mampu menghasilkan lulusan sebagaimana yang diharapkan oleh dunia kerja. Tenaga kerja yang dibutuhkan adalah sumber daya manusia yang memiliki kompetensi sesuai dengan bidang pekerjaannya, memiliki daya adaptasi dan daya saing yang tinggi. Atas dasar itu, pengembangan kurikulum dalam rangka penyempurnaan pendidikan menengah kejuruan harus disesuaikan dengan kondisi dan kebutuhan dunia kerja.

Perkembangan ilmu pengetahuan dan teknologi berdampak pada perubahan tuntutan dunia kerja terhadap sumber daya manusia yang dibutuhkan. Karena itu, pembelajaran di SMK harus bisa mengakomodasi dan mengantisipasi perkembangan ilmu pengetahuan dan teknologi. Substansi atau materi yang diajarkan di SMK disajikan dalam bentuk berbagai kompetensi yang dinilai penting dan perlu bagi peserta didik dalam menjalani kehidupan sesuai dengan zamannya. Kompetensi dimaksud meliputi kompetensi-kompetensi yang dibutuhkan untuk menjadi manusia Indonesia yang cerdas dan pekerja yang kompeten, sesuai dengan standar kompetensi yang ditetapkan oleh industri/dunia usaha/asosiasi profesi.

Pembelajaran berbasis kompetensi harus menganut prinsip pembelajaran tuntas (mastery learning) untuk dapat menguasai sikap (attitude), ilmu pengetahuan (knowledge), dan keterampilan (skills) agar dapat bekerja sesuai dengan profesinya seperti yang dituntut oleh suatu kompetensi. Agar dapat belajar secara tuntas, perlu dikembangkan prinsip pembelajaran sebagai berikut: (1) Learning by doing (belajar melalui aktivitas/kegiatan nyata, yang memberikan pengalaman belajar bermakna) yang dikembangkan menjadi pembelajaran berbasis produksi. (2) Individualized learning (pembelajaran dengan memperhatikan keunikan setiap individu) yang dilaksanakan dengan sistem modular.

Isu yang mengemuka dewasa ini adanya kesenjangan antara sekolah dengan kehidupan nyata di masyarakat. Apa yang dipelajari di sekolah, merupakan hal lain yang terjadi di masyarakat, sehingga disinyalir sekolah semakin menjauhkan peserta didik dengan dunia nyatanya di mana ia hidup dan bermasyarakat. Lulusan sekolah termasuk SMK belum sepenuhnya memiliki kompetensi atau kecakapan hidup. Kecakapan hidup ini meliputi: (a) kecakapan personal (personal skills) (b) kecakapan sosial (social skills), (c) kecakapan akademik (academic skills), dan (d) kecakapan vokasional (vocational skills). (Direktorat Pendidikan Menengah Kejuruan, 2004:16).

Berdasarkan hasil observasi di lapangan proses pembelajaran untuk kompetensi memperbaiki motor listrik pada kompetensi keahlian Teknik Instalasi Tenaga Listrik belum berjalan dengan efektif. Pelaksanaan pembelajaran materi memperbaiki motor listrik hanya menggunakan modul sebagai satu-satunya bahan ajar dan media pembelajaran yang ada. Sementara untuk mendapatkan kompetensi yang diinginkan proses pembelajaran harus ditunjang dengan sarana pembelajaran yang memadahi. Indikator dari belum efektifnya proses pembelajaran ini dapat dilihat dari hasil belajar siswa untuk materi tersebut. Hasil diskusi dengan teman sejawat (guru) mengungkapkan bahwa proses pembelajaran materi memperbaiki motor listrik tidak bisa efektif ketika hanya menggunakan modul sebagai bahan dan media pembelajaran. Perlu ada sarana atau media penunjang untuk melengkapi modul tersebut. Alasannya adalah ketika hanya menggunakan modul banyak istilah dan materi yang sulit difahami peserta didik, sehingga harus disampaikan secara berulang-ulang.

Masalah yang sama juga dirasakan oleh peserta didik. Hasil wawancara dengan beberapa peserta didik, mereka mengalami kesulitan belajar jika hanya menggunakan modul saja. Proses pelaksanaan pekerjaan untuk memperbaiki motor listrik belum tergambar secara jelas dalam modul. Mereka menginginkan adanya fasilitas penunjang untuk melengkapi modul yang sudah ada. Menjawab persoalan diatas, guru SMK sebagai fasilitator dalam pencapaian kompetensi siswa dituntut untuk kreatif mengelola pembelajaran. Salah satunya adalah dengan mencari alternative pemecahan diantaranya dengan mengembangkan media pembelajaran yang mampu menggantikan peran fasilitas yang dibutuhkan dalam proses pembelajaran.

Mengingat belum tersedianya alat penunjang pembelajaran memperbaiki motor listrik di SMK, penulis termotivasi untuk mengembangkan media pembelajaran untuk materi memperbaiki motor listrik dengan asumsi bahwa media ini dapat mengungkap obyek dan peristiwa seperti keadaan yang sebenarnya. Pertimbangan lain dalam pengembangan media pembelajaran ini antara lain adalah: (1) menyediakan media pembelajaran yang sesuai dengan tuntutan kurikulum dengan mempertimbangkan kebutuhan peserta didik, yakni media yang sesuai dengan karakteristik dan setting atau lingkungan sosial peserta didik, (2) membantu peserta didik dalam memperoleh alternatif media pembelajaran dari modul yang sudah ada, serta (3) memudahkan guru dalam melaksanakan pembelajaran.

Berdasarkan latar belakang masalah tersebut dapat dirumuskan masalah yang berkaitan dengan pengembangan media pembelajaran materi memperbaiki motor listrik antara lain: (a) Perlunya pengembangan media pembelajaran yang menjadi alternatif pemecahan masalah dalam proses pembelajaran materi memperbaiki motor listrik di SMK. (b) Perlunya media pembelajaran materi memperbaiki motor listrik di SMK untuk meningkatkan efektifitas belajar siswa. Pengembangan media pembelajaran untuk materi memperbaiki motor listrik di SMK bertujuan untuk mengembangkan media audiovisual untuk materi memperbaiki motor listrik dan menghasilkan media yang efektif dalam pembelajaran materi memperbaiki motor listrik. 


\section{LANDASAN TEORI}

\section{Pengertian Media Pembelajaran}

Media pembelajaran merupakan sarana dan sarana yang mempunyai fungsi sebagai penunjang efektifitas proses pembelajaran. Arsyad, (2011:3) mengemukakan bahwa kata media berasal dari bahasa Latin medius yang secara harfiah berarti tengah, perantara atau pengantar atau pengantar pesan dari pengirim kepada penerima pesan. Istilah perantara atau pengantar ini menurut Asyhar, (2010:2) digunakan karena fungsinya sebagai perantara atau pengantar pesan dan informasi dari si pengirim (sender) pesan kepada si penerima (receiver).

Sementara itu Asosiasi Teknologi dan Komunikasi Pendidikan (Association of Education and Communication Technology/AECT) di Amerika menurut Sadiman. Raharjo, Haryono, Raharjito, (2009:6) membatasi media sebagai segala bentuk dan saluran yang digunakan orang untuk menyalurkan pesan atau informasi.

Sedangkan kata pembelajaran merupakan terjemahan dari "intruction". Intruction diartikan sebagai proses interaksi antara guru dan siswa. Ini berbeda dengan istilah "mengajar dan belajar" yang konotasinya hanya guru yang aktif. Penggunaan istilah "pembelajaran" sebagai pengganti istilah lama "proses belajar-mengajar" sesungguhnya mengubah peran guru dalam proses pembelajaran. Asyhar, (2010:4) menegaskan bahwa guru tidak hanya "mengajar" melainkan "membelajarkan" peserta didik untuk mau belajar.

Pendapat yang sama juga dikemukakan oleh Arsyad, (2011:1) bahwa belajar adalah suatu proses yang kompleks yang terjadi pada diri setiap orang sepanjang hidupnya. Proses belajar itu terjadi karena adanya interaksi antara seseorang dengan lingkungannya. Oleh karena itu, belajar dapat terjadi kapan saja dan di mana saja.

Dari beberapa istilah media dan pembelajaran, Hanafiah dan Suhana, (2009:59) menyatakan bahwa media pembelajaran merupakan segala bentuk perangsang dan alat yang disediakan guru untuk mendorong siswa belajar secara cepat, tepat, mudah, benar tidak terjadinya verbalisme. Media pembelajaran merupakan alat bantu bagi peserta didik dalam rangka memperoleh pengalaman belajar. Asyhar, (2010:7) menambahkan, bahwa media pembelajaran dapat dipahami sebagai segala sesuatu yang dapat menyampaikan atau menyalurkan pesan dari sumber secara terencana sehingga terjadi lingkungan belajar yang kondusif, yakni penerima dapat melakukan proses belajar secara efisien dan efektif.

Gerlach dan Ely (1977) dalam Arsyad, (2011: 3) mengatakan bahwa media apabila dipahami secara garis besar adalah manusia, materi, atau kejadian yang membangun kondisi yang membuat siswa mampu memperoleh pengetahuan, keterampilan dan sikap. Dalam pengertian ini, guru, buku teks, dan lingkungan sekolah merupakan media. Dari beberapa pendapat diatas media pembelajaran dapat di artikan sebagai perantara atau pengantar pesan. Perantara itu bisa berupa manusia, materi, dan alat perantara lainnya yang dapat meningkatkan efektifitas dan efesiensi, serta daya tarik tersendiri dalam proses interaksi pada situasi belajar untuk memperoleh pengetahuan, keterampilan dan sikap.

\section{Dasar Penggunaan Media Pembelajaran}

Media pembelajaran dipandang sebagai alternatif strategi yang efektif dan efisien dalam proses pembelajaran. Ada beberapa landasan yang mendasari penggunaan media dalam pembelajaran. Landasan itu menurut Midun (2009) dalam Asyhar, (2010:17) antara lain adalah, landasan historis, landasan psikologis, landasan teknologis, dan landasan empiris. Sedangkan menurut Arsyad, (2011: 7) penggunaan media pembelajaran juga didasari oleh landasan teoritis.

1. Landasan Historis

Perkembangan konsep media dalam pendidikan berawal dari gerakan pembaruan dalam dunia pendidikan yang dinamakan pembelajaran visual (visual educational) pada tahun 1923. Asyhar, (2010:18) mengemukakan bahwa gerakan ini diilhami oleh aliran realisme dalam pendidikan pada abad ke-17 yang dipelopori oleh Johan Amos Comenius yang mengarang buku teks pendidikan yang pertama berjudul "orbit pictus" (dunia dalam gambar).

Saat itu Comenius melihat betapa sulitnya anak-anak Eropa yang tidak berbahasa Latin untuk belajar bahasa Latin. Bagi mereka bahasa Latin sangat abstrak. Oleh karena itu Comenius membuat buku yang setiap kata Latin yang harus dipelajari diberikan gambar bendanya disamping kata tersebut, sehingga bahasa yang dipelajari menjadi lebih nyata atau kongrit.

Perkembangan selanjutnya adalah dengan ditemukannya radio pada tahun 1930-an, sehingga muncul gerakan “audiovisual education” yang menekankan pentingnya penggunaan audiovisual dalam pembelajaran. Konsep pengajaran visual ini kemudian terus berkembang menjadi "audiovisual intruction" pada tahun 1940-an, yang kemudian terus timbul variasi nama seperti "audiovisual material", "audiovisual methods", "ausiovisual devices". Pada intinya guru menggunakan berbagai alat atau bahan, metode dalam penyampaian ide, gagasan, dan pengalaman kepada peserta didik.

Gerakan pengembangan media ini terus muncul dengan konsep-konsep baru antara lain, tahun 1950-an muncul gerakan "audiovisual communication" yang memandang pendidikan sebagai proses komunikasi. Tahun 1952 muncul konsep "instructional materials" yang merupakan aplikasi proses komunikasi dan sistem dalam merencanakan dan mengembangkan materi pembelajaran. Asyhar, (2010:20) menjelaskan bahwa puncak dari perkembangan tersebut terjadi pada tahun 1990-an. Dengan penampilan pendekatan sistem teori komunikasi 
pengembangan sistem pembelajaran, dan pengaruh psikologi behaviorisme, maka muncul konsep "educationnal technology" atau "instructional technology" dimana media pembelajaran merupakan bagian dari padanya.

2. Landasan Psikologis

Belajar adalah suatu proses yang dapat mengakibatkan perubahan prilaku oleh adanya pengalaman yang telah didapat. Perubahan tersebut dapat berupa pengetahuan, keterampilan dan sikap. Menurut Asyhar, (2010:22) pengetahuan dan pengalaman peserta didik diperoleh melalui pintu gerbang alat indera. Karena itu diperlukan rangsangan (menurut teori behavioris) atau informasi (menurut teori kognitif) sehingga respon terhadap rangsangan atau informasi yang telah diperoleh itulah hasil belajar.

Sadiman, dkk (2009:11) juga mengemukakan bahwa belajar pada hakekatnya adalah proses komunikasi, yaitu proses penyampaian pesan dari sumber pesan melalui saluran/media tertentu ke penerima pesan. Pesan yang disampaikan adalah berupa ajaran atau didikan yang ada dalam kurikulum. Pesan itu dituangkan ke dalam simbolsimbol komunikasi baik simbol verbal (kata-kata lisan atau tertulis) maupun dalam simbol non verbal atau visual. Proses penuangan tersebut disebut encoding, sedang proses penafsiran simbol-simbol komunikasi yang mengandung pesan tersebut disebut decoding.

Menurut Jean Piaget (Asyhar. 2010:23) tingkat berfikir seseorang sesuai dengan perkembangan usianya. Sesuai dengan tingkat berfikirnya, setiap peserta didik diberi rangsangan yang berbeda, sehingga rangsangan itu dapat direspon dengan mempengaruhi prilaku yang diharapkan. Manusia belajar karena adanya interaksi dengan lingkungan. Dalam pengenalan dengan lingkungan itu, seseorang melewati tiga tahap belajar yaitu tingkat kongret, tingkat skematis, dan tingkat abstrak.

Tahapan kongret dialami oleh seseorang pada saat ia mengenal objek diluar dirinya secara riil atau nyata. Pada masa ini seseorang mengenal benda berdasarkan apa yang dilihat dan apa yang diraba. Tahapan skematis dialami oleh mereka yang telah mampu membuat skema atau saling menghubungkan antara beberapa hal. Mereka akan memahami hal yang dipelajari karena telah menyusun suatu skema. Tahapan abstrak dialami oleh pebelajar pada saat mereka telah mampu memahami objek atau benda pada konsep abstrak, atau mereka telah mampu membuat abstraksi tentang sesuatu.

Dari tahapan belajar ini dapat dikatakan bahwa belajar adalah proses yang kompleks dan unik. Asyhar, (2010:24) mengemukakan bahwa seseorang yang belajar melibatkan segala aspek kepribadiannya, baik fisik maupun mental. Kepribadian ini tampak dari prilaku belajar seseorang. Keunikan prilaku belajar ini disebabkan oleh adanya perbedaan karakter yang menetukan prilaku belajar atau gaya belajar. Prilaku yang kompleks ini kemudian menuntut layanan dan perlakuan pembelajaran yang kompleks dan unik pula.

Komponen pembelajaran yang bertanggungjawab dalam masalah ini adalah strategi penyampaian pembelajaran, lebih khusus lagi media pembelajaran. Media pembelajaran harus dipilih sesuai dengan karakteristik individu peserta didik, sesuai dengan tahapan belajar dan gaya belajarnya. Jika peserta didik mempunyai gaya belajar visual harus mendapatkan rangsangan belajar visual. Menurut taksonomi Briggs terhadap media pembelajaran yang dikemukakan oleh Sadiman. dkk, (2009:23) bahwa stimulus atau rangsangan dapat ditimbulkan dari media, yaitu kesesuaian rangsangan tersebut dengan karakteristik siswa.

3. Landasan Teknologis

Sasaran akhir dari teknologi pembelajaran adalah memudahkan belajar peserta didik. Untuk mencapai sasaran akhir ini para teknolog di bidang pembelajaran mengembangkan berbagai sumber belajar untuk memenuhi kebutuhan setiap peserta didik sesuai dengan karakteristiknya. (Asyhar, 2010:25). Kegiatan pengembangan desain, produksi, evaluasi dan pemilihan media serta kegiatan penggunaan media pembelajaran ini telah dilakukan oleh para teknolog. Mereka berpijak pada prinsip bahwa suatu media akan mempunyai keunggulan bila digunakan oleh peserta didik yang mempunyai karakter belajar sesuai dengan rangsangan yang ditimbulkan oleh media pembelajaran tersebut.

Dengan demikian penggunaan media pembelajaran dapat meningkatkan produktivitas pendidikan, memberikan kemungkinan pembelajaran yang sifatnya lebih individual, memberi dasar lebih ilmiah pada pembelajaran. Selain itu proses pendidikan juga dapat menjadi lebih langsung dan akses pendidikan menjadi lebih sama bagi semua peserta didik.

4. Landasan Empiris

Berbagai penelitian telah menunjukkan bahwa ada interaksi antara penggunaan media pembelajaran dan karakteristik belajar peserta didik dalam menentukan hasil belajar. (Asyhar, 2010:28). Peserta didik akan mendapat keuntungan yang berarti bila belajar dengan menggunakan sumber dan media pembelajaran yang sesuai dengan karakteristik dan gaya belajarnya.

\section{Landasan Teoretis}

Pengetahuan dan keterampilan maupun perubahan sikap dan prilaku dapat diperoleh karena adanya interaksi antara pengalaman baru dan pengalaman yang pernah dialami sebelumnya. Menurut Bruner (1966) dalam Arsyad, (2011:7) ada tiga tingkatan utama modus belajar, yakni pengalaman langsung (enactive), pengalaman piktorial/gambar (iconic), dan pengalaman abstrak (symbolic). Ketiga tingkat pengalaman ini saling berinteraksi dalam upaya memperoleh pengalaman (pengetahuan, keterampilan, dan sikap) yang baru. Belajar dengan menggunakan indera ganda pandang dan 
dengar berdasarkan konsep itu dapat memberi keuntungan bagi peserta didik. Peserta didik akan belajar lebih banyak daripada jika materi pelajaran disajikan hanya dengan stimulus pandang saja atau dengar saja. Para ahli memiliki pandangan yang sama tentang stimulus yang diterima oleh indera peserta didik. Perbandingan pemerolehan hasil belajar melalui indera pandang dan indera dengar sangat menonjol perbedaannya. Bough dalam Achin (1986) yang dikutip Arsyad, (2011:10) mengemukakan bahwa kurang lebih 90\% hasil belajar seseorang diperoleh melalui indera pandang, dan hanya sekitar 5\% diperoleh melalui indera dengar dan 5\% lagi dari indera lainnya. Sedangkan Dale (1969) dalam Arsyad, (2011:10) memperkirakan bahwa pemerolehan hasil belajar melalui indera pandang berkisar 75\%, melalui indera dengar $13 \%$, dan melalui indera lainnya sekitar $12 \%$.

Salah satu gambaran yang paling banyak dijadikan acuan sebagai landasan teori penggunaan media dalam proses belajar menurut Arsyad, (2011:10) adalah Dale's Cone of Experience (kerucut pengalaman Dale) seperti gambar berikut:
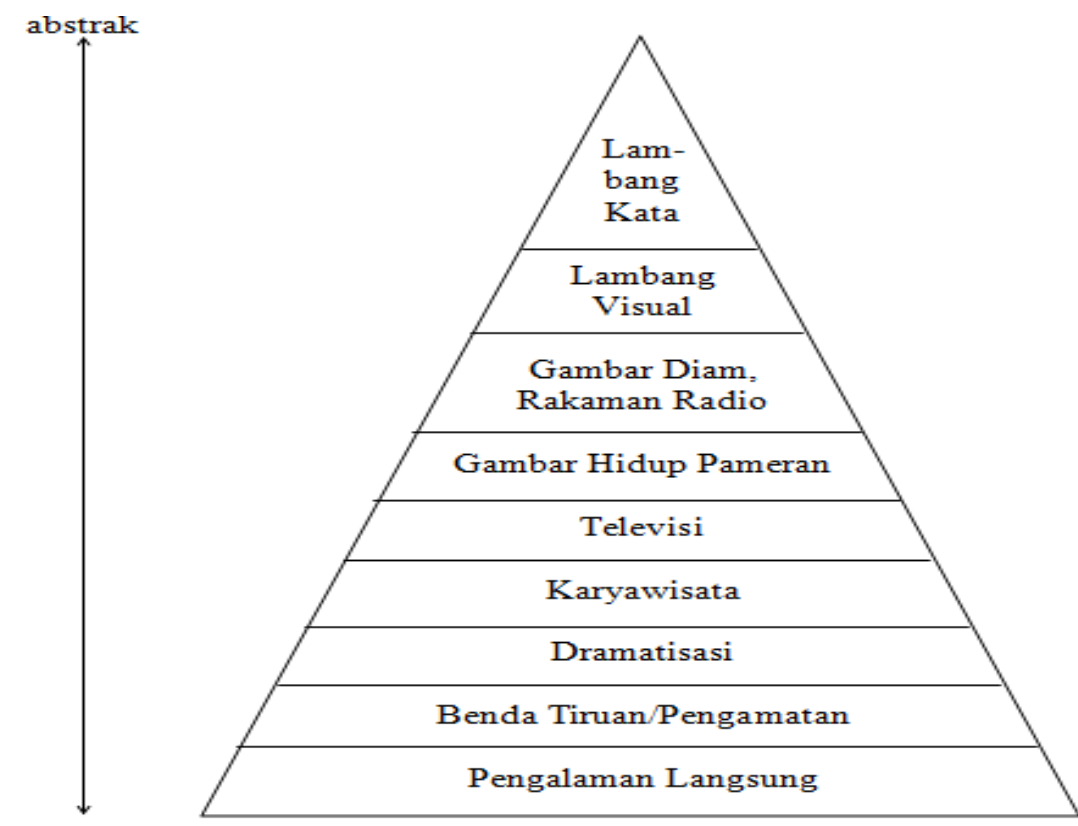

Kongrit

\section{Gambar 1. Kerucut pengalaman Edgar Dale}

Kerucut itu merupakan elaborasi yang rinci dari konsep tiga tingkatan pengalaman yang dikemukakan oleh Bruner sebagaimana yang telah diuraiakan sebelumnya. Hasil belajar seseorang dimulai dari pengalaman langsung kenyataan yang ada di sekitar lingkungan, kemudian melalui benda tiruan, sampai kepada lambang verbal (abstrak). Semakin keatas semakin abstrak media penyampai pesan itu. Namun hal ini bukan berarti bahwa proses pembelajaran dan interaksi mengajar harus selalu dimulai dari pengalaman langsung, tetapi dimulai dari jenis pengalaman yang paling sesuai dengan kebutuhan dan kemampuan kelompok peserta didik yang dihadapi dengan mempertimbangkan situasi belajarnya.

\section{Teori Kognisi Pembelajaran Multimedia}

Setiap orang memiliki tipe yang berbeda dalam memproses informasi yang diterimanya. Ada yang memiliki tipe visual dan tipe auditori. Orang yang memiliki tipe visual memproses informasi dengan mengandalkan indera penglihatannya, sedangkan orang yang memiliki tipe auditori akan memproses informasi dengan indera pendengarannya.

Menurut Mayer, (2009:64) ada tiga asumsi yang mendasari teori kognisi pembelajaran multimedia, yakni saluran ganda (dual-channel), kapasitas terbatas (limited capacity), dan pemrosesan aktif (active processing). Mayer, (2009:68) menjelaskan bahwa asumsi saluran ganda (dual-channel) beranggapan bahwa manusia memiliki saluran terpisah untuk memproses informasi visual dan informasi auditori. Saat informasi disajikan ke mata dalam bentuk ilustrasi, animasi, video, atau teks, manusia memulai memproses informasi tersebut ke saluran visual. Sesangkan saat informasi disajikan pada telinga dalam bentuk narasi atau suara-suara non verbal, manusia memulainya dengan memproses informasi itu dalam saluran auditori.

Asumsi kapasitas terbatas (limited capacity) beranggapan bahwa manusia mempunyai keterbatasan atas jumlah informasi yang bisa diproses dalam masing-masing saluran pada saat tertentu. Saat ilustrasi atau animasi disajikan, orang hanya dapat menampung beberapa informasi di dalam memori kerjanya. Artinya tidak seluruh informasi dapat ditampung pada memori. Begitu juga saat narasi disajikan, orang kemungkinan hanya dapat menampung sebagian kata-kata yang disajikan di memori kerjanya pada saat tertentu. 
Asumsi berikutnya dalah asumsi pemrosesan aktif (active processing). Mayer, (2009:74) beranggapan bahwa manusia secara aktif akan melibatkan dalam pemrosesan informasi untuk mengkontruksi representasi mental yang saling terkait terhadap pengalaman mereka. Proses kognisi aktif ini meliputi: memberikan perhatian, menata informasi nyang masuk, dan memadukan antara informasi yang masuk dengan pengetahuan lainnya. Lebih lanjut Mayer, (2009:75) menyebutkan bahwa manusia adalah prosesor aktif yang berusaha untuk menalar setiap presentasi multimedia.

Berangkat dari tiga asumsi tersebut maka pusat pembelajaran multimedia berlangsung dalam memori kerja. Memori kerja (working memory) digunakan untuk menyimpan sementara dan memanipulasi pengetahuan dalam kesadaran pikiran aktif. Untuk lebih jelas pemrosesan informasi ini dapat dilihat pada gambar berikut:

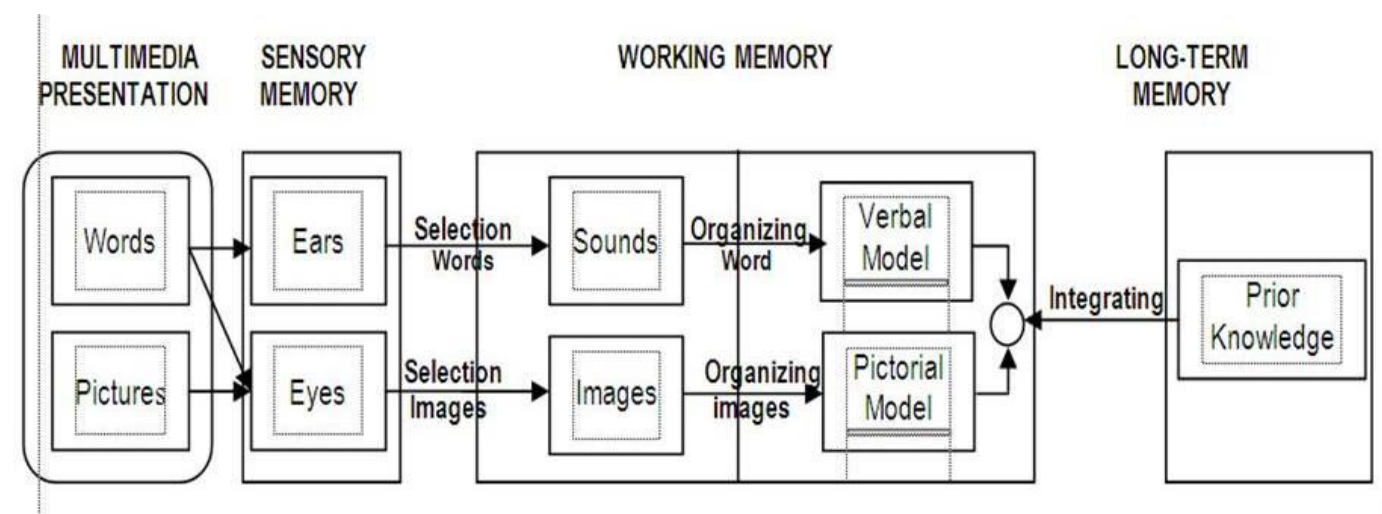

Gambar 2. Teori Kognisi Tentang Multimedia Learning

Dalam gambar itu dapat dipahami bahwa sisi kiri berlabel memori kerja (Working Memory) mewakili jenis materi mentah yang masuk ke dalam memori kerja, yakni citra visual berupa gambar (pictures) dan citra suara berupa kara-kata (words). Hal itu didasarkan pada dua indrawi pada diri manusia yaitu mata dan telinga. Sisi kanan memori kerja (Working Memory) mewakili pengetahuan yang sudah terkontruksi di memori kerja berupa model-model mental verbal dan visual serta keterkaitan diantara keduanya.

Mayer, (2009:66) selanjutnya menjelaskan bahwa tanda panah yang menghubungkan dari suara ke gambar merupakan konversi mental dari suara menjadi informasi gambar. Misalnya saat mendengar kata "kucing" maka seseorang kemungkinan akan membetuk gambaran mental (membayangkan) bentuk kucing. Begitu juga sebaliknya, informasi visual dapat dikonversi menjadi informasi suara. Misalnya seseorang akan merasakan kata "kucing" dibunyikan saat melihat gambar kucing.

Dari contoh tersebut dapat dipahami bahwa proses kognisi ini dapat terjadi dengan asosiasi mental dengan kata-kata yang terucap bisa memunculkan gambaran tentang wujud dari apa yang diucapkan dan sebaliknya. Mayer menegaskan bahwa dalam gambar itu, pemrosesan kognisi utama yang dipersyaratkan untuk pembelajaran multimedia ini dipresentasikan oleh panah-panah yang berlabel memilih gambar (Selection images), memilih kata (selection words), menata kata (organizing word), menata gambar (organizing images) dan memadukannya. Akhirnya kotak diujung kanan diberi istilah memori jangka panjang. Memori ini saling terkait dengan pengetahuan seseorang. Tidak seperti memori kerja, memori jangka panjang ini bias menampung pengetahuan yang sangat banyak dan dalam waktu yang lama.

Berdasarkan tiga asumsi yang telah digambarkan tadi, Mayer, (2009:79) menegaskan bahwa berdasarkan tiga asumsi yang telah digambarkan itu, menghadirkan teori kognitif tentang pembelajaran multimedia. Dalam pembelajaran multimedia yang materinya disajikan lebih dari satu format (kata, gambar, suara), agar pembelajaran lebih bermakna, orang yang belajar harus melibatkan diri ke dalam lima proses kognitif: (1) memilih kata-kata yang relevan untuk pemrosesan dalam memori kerja verbal, (2) memilih gambar yang relevan untuk pemrosesan dalam memori kerja visual, (3) menata kata-kata yang terpilih ke dalam model mental verbal, (4) menata gambar-gambar yang terpilih ke dalam model mental visual, dan (5) memadukan representasi verbal dan visual dengan pengetahuan yang sudah ada sebelumnya. Pembelajaran multimedia yang berhasil menuntut orang untuk mengkoordinasikan dan memantau lima proses ini.

\section{METODE PENELITIAN}

Model pengembangannya yang dipilih adalah berdasarkan pada model Borg dan Gall. Model ini sesungguhnya mengadopsi secara penuh model design pembelajaran Dick dan Carey, dengan sembilan langkah, yakni: (1) mengidentifikasi tujuan umum pembelajaran, (2) mengadakan analisis pembelajaran, (3) mengidentifikasi karakteristik dan kemampuan awal, (4) merumuskan tujuan khusus pembelajaran, (5) mengembangkan tes acuan 
patokan, (6) mengembangkan strategi pembelajaran, (7) mengembangkan dan memilih bahan pembelajaran, (8) merancang dan mengadakan evaluasi formatif, dan (9) merevisi pembelajaran.

Prosedur penelitian pengembangan menurut Borg dan Gall, dapat dilakukan dengan lebih sederhana melibatkan 5 langkah utama:

1. Melakukan Analisis

Sebelum melakukan perancangan sebuah produk terlebih dahulu perlu dilakukan analisis. Analisis ini bertujuan agar produk yang dikembangkan dapat mempunyai nilai ketermanfaatan yang tinggi. Beberapa hal yang perlu dianalisis antara lain:

a. Analisis Kebutuhan

Analisis kebutuhan dilakukan telaah terhadap kompetensi yang diharapkan dicapai oleh peserta didik. Kompetensi didasarkan pada tuntutan keterampilan yang harus dimiliki oleh peserta didik materi memperbaiki motor listrik. Telaah kompetensi tersebut dilakukan untuk memperoleh gambaran tentang kebutuhan media pembelajaran yang sesuai.

b. Analisis Karakteristik Siswa

Analisis karakteristik siswa bertujuan untuk mengetahui karakteristik calon pengguna dalam hal ini adalah siswa. Analisis ini diperlukan untuk melihat seberapa jauh ketertarikan siswa terhadap jenis media yang akan dikembangkan.

c. Analisis Ketersediaan Fasilitas Penunjang

Analisis ini didasarkan pada kondisi di sekolah berkaitan dengan perlengkapan penunjang pembelajaran dan proses pembelajaran memperbaiki motor listrik itu sendiri. Ketersediaan fasilitas penunjang terutama di sekolah sangat menentukan apakah produk dapat mempunyai nilai manfaat atau tidak. Dengan fasilitas penunjang yang cukup, maka produk yang dikembangkan akan dapat digunakan di sekolah tersebut.

d. Analisis Kemampuan Pengguna

Kemampuan pengguna terutama guru sangat penting untuk dianalisis. Sebuah produk akan mempunyai daya guna yang tinggi ketika dapat dengan mudah dioperasikan. Analisis ini bertujuan untuk memperoleh gambaran terhadap penggunaan produk yang dikembangkan.

2. Merancang produk awal

Setelah analisis kebutuhan telah dilaksanakan, selanjutnya pengembangan media pembelajaran ini mulai merancang produk. Perancangan produk dilakukan dengan beberapa tahap antara lain:

a. Penyusunan Naskah Atau Draf

Naskah dalam penyusunan media pembelajaran adalah pedoman tertulis yang berisi informasi dalam bentuk visual, grafis, dan audio yang dijadikan acuan dalam pembuatan (produksi) media pembelajaran. Naskah diperlukan karena media pembelajaran yang akan dibuat mengandung isi materi dan kompetensi yang diharapkan dapat tercapai. Melalui naskah ini tujuan dan materi dalam media pembelajaran dapat dituangkan dengan kemasan tertentu. Dalam naskah tersebut ditulis secara jelas unsur-unsur audio, teks dan visual yang harus ditampilkan dalam media pembelajaran beserta urutannya dengan jelas tertera. (Asyhar, 2010:163)

b. Membuat Story Board/Shooting Script

Story Board adalah petunjuk operasional dalam kegiatan produksi, pembuatan program dan pengambilan gambar. Di dalam Story Board sudah tergambar secara lengkap dan sistematis setiap adegan bahkan shoot (gambar) yang akan diambil, misalnya siapa yang muncul, bagaomana gerakan, dimana posisi obyek, dan melakukan apa, dimana posisi camera dan angle camera serta bagaimana cara mengambil gambarnya. (Asyhar, 2010:172)

c. Pengambilan Gambar dan Suara

Langkah produksi selanjutnya adalah pengambilan gambar dan suara. Kegiatan produksi ini harus mencari dan mendapatkan gambar dan suara yang mempunyai kualitas yang baik sesuai dengan yang diinginkan (sesuai dengan tujuan pembuatan media pembelajaran) dan berpedoman pada Story Board yang telah dibuat.

d. Editing

Editing adalah kegiatan merangkai gambar dengan gambar, suara dengan suara, dan gambar dengan suara menjadi satu rangkaian yang kronologis sehingga media pembelajaran mampu menyampaikan pesan yang diinginkan dalam tujuan pembelajaran serta menarik. Proses editing diakhiri dengan melakukan preview untuk melihat hasil secara keseluruhan media pembelajaran yang dibuat.

3. Validasi ahli dan revisi

Validasi adalah proses permintaan persetujuan atau pengesahan terhadap kesesuaian media pembelajaran dengan kebutuhan. (Asyhar, 2010:223). Validasi dilakukan dengan melibatkan pihak praktisi yang ahli sesuai dengan bidang-bidang yang terkait dalam media pembelajaran tersebut. Dalam media pembelajaran ini validasi meliputi isi materi atau substansi dari media pembelajaran, penggunaan bahasa, dan kualitas gambar dan suara yang 
dihasilkan. Revisi produk media pembelajaran dilakukan berdasarkan komentar dan saran dari masing-masing validator. Setelah dilakukan revisi maka media pembelajaran siap untuk dilakukan uji coba.

4. Ujicoba lapangan kelompok kecil dan revisi produk

Setelah dilakukan revisi sesuai dengan saran dari tim ahli selanjutnya media pembelajaran dianggap layak untuk dilakukan uji coba lapangan. Uji coba pertama dilakukan kepada peserta didik dalam kelompok kecil, antara 5 - 10 siswa. Uji coba ini dilakukan untuk mengetahui keterlaksanaan dan manfaat serta efektifitas penggunaan media pembelajaran dalam pembelajaran. Selanjutnya dilakukan revisi atau penyempurnaan produk berdasarkan saran dan komentar dari siswa. (Asyhar, 2010:222)

5. Uji coba lapangan kelompok besar dan produk akhir

Uji coba kedua dilaksanakan dalam kelompok siswa yang lebih besar (satu kelas). Tujuan dari uji coba ini adalah untuk mengetahui kemampuan peserta didik dalam memahami materi pelajaran dan mengetahui efesiensi waktu belajar menggunakan media yang diproduksi. (Asyhar, 2010:222)

\section{Uji Coba Produk}

\section{Desain Uji Coba}

Berdasarkan prosedur pengembangan media pembelajaran memperbaiki motor listrik maka uji coba didesain dengan sekema berikut:

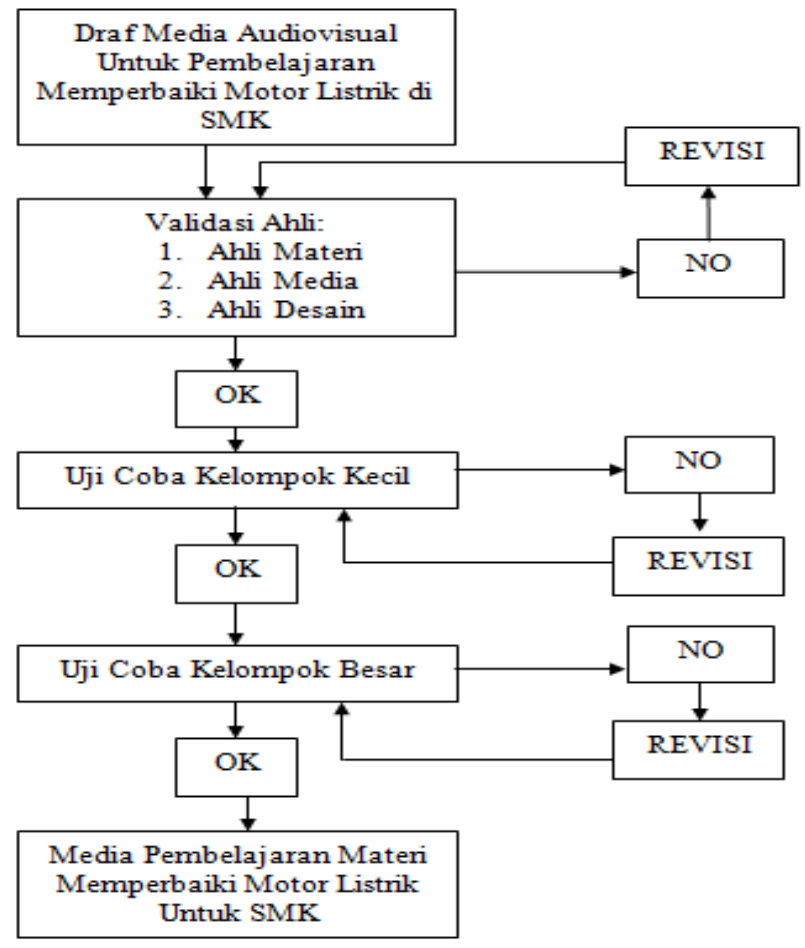

Gambar 3: Skema desain uji coba produk media pembelajaran

\section{Subjek Uji Coba untuk Evaluasi}

Subjek uji coba pengembangan media pembelajaran ini antara lain:

a. Validator Ahli Isi/Materi

Validator ahli materi yang dipilih adalah orang yang ahli Bidang Mesin-mesin Listrik, dengan kualifikasi pendidikan minimal Sarjana Strata 2 (S2) Bidang Listrik . Peranannya memvalidasi isi atau materi dalam media pembelajaran memperbaiki motor listrik, kaitannya dengan kesesuaian materi dengan tuntutan kompetensi sesuai dengan kurikulum.

b. Validator Ahli Media

Ahli media yang dipilih adalah orang yang berkompeten bidang media khususnya media pembelajaran dengan kualifikasi pendidikan minimal Sarjana Strata 2 (S2). Peranannya adalah memberikan penilaian, saran dan pengesahan, terhadap mutu atau kualitas dari media pembelajaran baik kualitas gambar maupun kualitas suara, serta kualitas tampilan secara keseluruhan.

c. Validari Ahli Desain

Ahli desain yang dipilih adalah orang yang berkompeten dalam bidang desain pembelajaran. Peranannya adalah untuk memberikan penilaian dan pengesahan terhadap desain pembelajaran yang menggunakan media audiovisual memperbaiki motor listrik.

d. Uji Coba Sasaran 
Uji coba sasaran yang dimaksud disini adalah pengguna produk pengembangan, yaitu siswa SMK Kompetensi Keahlian Teknik Instalasi Tenaga Listrik. Peran dari subjek ini untuk mengetahui keterlaksanaan dan manfaat serta efektifitas penggunaan media pembelajaran dalam pembelajaran dan mengetahui kemampuan peserta didik dalam memahami media pembelajaran serta mengetahui efisiensi waktu belajar menggunakan media pembelajaran yang diproduksi

\section{HASIL DAN PEMBAHASAN}

Hasil pengembangan media audiovisual untuk pembelajaran memperbaiki motor listrik di SMK ini diperoleh dari data kegiatan validasi dan uji coba. Data ini diklasifikasi berdasarkan jenis dan komponen dari produk yang dikembangkan. Dari data yang diperoleh selanjutnya dianalisis untuk mendapatkan kesimpulan yang dijadikan sebagai dasar dalam melakukan revisi produk.

Pembahasan hasil penelitian pengembangan mempunyai arti penting bagi keseluruhan penelitian. Dalam pembahasan ini temuan-temuan dan data yang diperoleh dari proses penelitian pengembangan (validasi dan uji coba lapangan) diinterpretasikan dan ditafsirkan. Hasil dari penafsiran yang merupakan hasil penelitian ini selanjutnya diintegrasikan ke dalam produk akhir yang dikembangkan.

Berdasarkan masukan dan saran dari ahli materi, ahli media dan ahli desain pada proses validasi, ada beberapa pernyataan penting yakni:

1. Media disusun berdasarkan analisis kebutuhan

Saran ini disampaikan oleh ahli materi. Menurutnya, dalam proses pembelajaran tidak bisa lepas dari strategi penyampaian pembelajaran. Media yang akan dikembangkan harus sesuai dengan hal-hal yang diperlukan dalam kegiatan belajar. Pernyataan diperkuat oleh Wena, (2010:8) yang mengatakan bahwa strategi pembelajaran menekankan pada media apa yang digunakan, kegiatan belajar apa yang akan dilakukan siswa dan struktur belajar mengajar bagaimana yang akan digunakan. Martin dan Briggs (1996) dalam Wena, (2010:9), juga menyatakan bahwa media adalah semua sumber yang diperlukan untuk melakukan komunikasi dengan siswa. Dengan demikian media lebih tepat jika disusun berdasarkan analisis kebutuhan dalam proses pembelajaran yang akan direncanakan. Analisis kebutuhan dilakukan agar media yang dikembangkan betul-betul sesuai dengan yang dibutuhkan.

2. Media harus sesuai dengan tujuan pembelajaran

Tujuan utama pengembangan media adalah mempercepat proses pemahaman siswa terhadap isi atau materi pelajaran. Dengan demikian media pembelajaran hendaknya disusun sesuai dengan tujuan pembelajaran. Menurut Degeng (1989) dalam Wena, (2010:10) dalam proses pembelajaran, media yang digunakan guru harus sesuai dengan tujuan pembelajaran termasuk juga materi, standar kompetensi, dan kompetensi dasar yang telah ditetapkan. Interaksi media pembelajaran dengan siswa pada akhirnya akan mampu mempercepat proses pemahaman untuk mencapai tujuan pembelajaran.

3. Media disusun berdasarkan tahapan pencapaian kompetensi

Media pembelajaran merupakan segala bentuk perangsang dan alat yang disediakan guru untuk mendorong siswa belajar secara cepat, tepat, mudah, benar dan tidak terjadi verbalisme. (Hanafiah dan Suhana, 2009:59). Media ini juga merupakan alat bantu (pendengaran dan penglihatan) bagi peserta didik dalam rangka memperoleh pengalaman belajar secara signifikan. Salah satu karakteristik dalam pendekatan kontruktivisme, menurut Hanafiah dan Suhana, (2009:63), proses belajar merupakan integrasi pengetahuan baru dengan pengetahuan lama.

Dari pernyataan tersebut, jika dikaitkan dengan pencapaian kompetensi siswa yang diperoleh secara bertahap, maka tahapan pencapaian kompetensi ini sangat tergantung dari informasi atau pengetahuan yang diterima oleh siswa. Informasi yang baru akan terintegrasi dengan informasi sebelumnya dan membentuk suatu pengetahuan baru. Oleh karena itu informasi yang masuk secara bertahap ini hendaknya sesuai dengan struktur materi pelajaran agar proses pengintegrasian informasi baru dan informasi sebelumnya dapat dilakukan dengan mudah oleh siswa. Media sebagai salah satu sumber informasi tentunya juga harus disusun berdasarkan tahapan pencapaian kompetensi dari materi pelajaran yang disampaikan.

4. Bagian penting dari materi divisualisasikan untuk memberikan daya tarik

Menurut validator ahli media, media audiovisual mempunyai kekuatan pada visualisasi dari bagian-bagian penting materi pelajaran. Sebagai penyampai pesan, media pembelajaran harus mampu memberikan kesan dalam rangka memperoleh pengalaman belajar. Trianto, (2007:75) menjelaskan bahwa media pembelajaran ini diharapkan dapat memberikan manfaat, antara lain: (1) Bahan yang disajikan menjadi jelas maknanya bagi siswa, dan tidak bersifat verbalistik: (2) Metode pembelajaran lebih bervariasi: (3) Siswa menjadi lebih aktif melakukan beragam aktifitas. (4) Pembelajaran lebih menarik, dan (5) dapat mengatasi keterbatasan ruang. Dengan visualisasi ini kegiatan yang dilakukan oleh model dalam media dapat memberikan contoh kongkrit yang menyerupai kegiatan yang sebenarnya. 
Arsyad, (2011:17) menambahkan bahwa berdasarkan fungsi kognitif media, lambing visual atau gambar dapat memperlancar pencapaian tujuan untuk memahami dan mengingat informasi atau pesan yang terkandung dalam gambar. Oleh karena itu bagian-bagian penting dari materi pelajaran sebagai pesan utama perlu divisualisasikan dengan jelas dan menarik.

5. Penggunaan media dalam pembelajaran

Dari produk media pembelajaran ini ahli desain memberikan saran bahwa dalam pembuatan media perlu dipertimbangkan dan direncanakan penggunaannya pada pembelajaran. Trianto, (2007:75) menegaskan bahwa media pembelajaran hanya meliputi media yang dapat digunakan secara efektif dalam proses pembelajaran yang terencana. Sedangkan menurut Gagne (1985) yang dikutip oleh Degeng (1989) dalam Wena, (2010:10) bahwa pembelajaran yang efektif harus dilakukan dengan berbagai cara dan menggunakan berbagai media pembelajaran. Berkaitan dengan penggunaan media, guru harus memiliki kiat maupun seni untuk memadukan antara bentuk pembelajaran (desain) dan media yang digunakan sehingga mampu menciptakan proses pembelajaran yang harmonis. Artinya guru harus mampu merancang pembelajaran yang menggunakan media secara tepat sesuai dengan fungsinya, alokasi waktunya dan kapan media tersebut harus digunakan.

Uji coba lapangan dilakukan terhadap calon pengguna. Uji coba kelompok kecil bertujuan untuk mengetahui keterlaksanaan dan manfaat serta efektifitas penggunaan media pembelajaran dalam proses pembelajaran. Sedangkan uji coba kelompok besar betujuan mengetahui kemampuan peserta didik dalam memahami materi/isi dari media tersebut serta mengetahui efisiensi waktu belajar menggunakan media pembelajaran yang diproduksi. Dari proses uji coba tersebut menghasilkan beberapa data dan pernyataan mengenai produk media yang diujicobakan. Data dan pernyataan ini antara lain:

\section{Kualifikasi Media}

Menurut responden sebagai sasaran uji coba, secara keseluruhan kualifikasi telah menunjukkan sangat baik. Media audiovisual untuk pembelajaran memperbaiki motor listrik di SMK ini telah memenuhi unsur penting dari media yakni: gambar, suara, teks dapat terlihat dan terdengar dengan jelas. Gambar dalam media ini juga dapat mewakili benda aslinya dan berfungsi sebagai penyampai pesan sesuai dengan materi pelajaran dan disajikan dalam tayangan yang menarik. Penayangan media ini juga sudah sesuai dengan urutan materi dengan durasi penayangan yang sesuai.

\section{Pemanfaatan Media}

Selain kualifikasi media, responden dalam uji coba prodak juga memberikan saran agar media tersebut dapat dimanfaatkan dalam proses pembelajaran di sekolah. Alasannya adalah, media ini dapat memberikan informasi dengan jelas langkah-langkah pekerjaan pada materi memperbaiki motor listrik sehingga memberi kemudahan dalam pembelajaran. Kemudahan ini dibuktikan dengan hasil uji coba kelompok besar yang memberikan kesimpulan adanya peningkatan hasil belajar. Dengan demikian media dapat mempercepat pemahaman materi pelajaran.

Produk akhir media ini adalah hasil pengintegrasian pernyataan-pernyataan penting dari proses pengembangan media. Dari hasil pengintegrasian tersebut diperoleh sebuah media audiovisual untuk pembelajaran memperbaiki motor listrik di SMK dengan karakteristik sebagai berikut:

1. Media ini menayangkan proses pekerjaan dalam memperbaiki motor listrik dalam gambar bergerak yang diperagakan oleh model. Setiap jenis kegiatan belajar ditampilkan secara detail sehingga memudahkan pengguna untuk mengikuti atau memperagakan langkah-langkah yang dilakukan oleh model dalam video tersebut.

2. Memperhatikan saran dan pernyataan ahli media, Media pembelajaran ini merupakan media audiovisual berupa video pembelajaran yang menampilkan unsur gambar (visual) dan suara secara bersamaan. Bagian-bagian penting divisualisasikan dengan baik agar mudah dipahami dan menarik.

3. Masukan dari ahli desain menjadi pertimbangan untuk membuat produk media yang sesuai untuk digunakan dalam proses pembelajaran di sekolah. Petunjuk penggunaan media yang ditayangkan pada segmen pembukaan memberikan arahan kepada guru bagaimana sebaiknya menggunakan media ini.

Deskripsi kualitatif dari produk pengembangan diuraikan berdasarkan kesimpulan dari interprestasi dan penafsiran, termasuk implikasi dari produk yang dihasilkan. Dalam pembahasan ini ada dua hal yang perlu diuraikan dari kualitas produk, yakni terhadap ketercapaian tujuan pengembangan itu sendiri dan terhadap implikasi lain yang tidak termasuk dalam tujuan pokok pengembangan tetapi mempunyai arti penting dalam pengembangan media.

Tujuan pengembangan seperti yang telah diuraikan pada bab-bab sebelumnya adalah tersedianya media audiovisual, sebagai media yang efektif dalam pembelajaran memperbaiki motor listrik di SMK. Dari deskripsi kualitas produk yang diperoleh dari masukan dan saran pada saat validasi dan uji coba lapangan maka tujuan pengembangan produk ini telah terpenuhi. Dengan menggunakan media ini proses pembelajaran dapat berjalan dengan efektif. Indikator dari efektif dalam pembelajaran ini adalah adanya peningkatan dalam pemahaman materi memperbaiki motor listrik.

Selain terhadap ketercapaian tujuan pengembangan, ada implikasi lain yang cukup penting atau dampak pengiring dari produk yang dihasilkan. Diantaranya, dengan adanya media audiovisual untuk pembelajaran memperbaiki motor listrik di SMK ini memberikan dampak psikologi bagi siswa seperti sikap, minat, motivasi. Media 
ini juga memberikan pengauh terhadap kegiatan belajar. Dengan menggunakan media proses pembelajaran akan berjalan dengan berbagai variasi dan tidak membosankan, sehingga belajar bias menjadi lebih menarik.

Selanjutnya produk akhir dari media audiovisual untuk pembelajaran memperbaiki motor listrik di SMK ini masih mempunyai beberapa keterbatasan, antara lain: (1) Pengadaan media memerlukan biaya mahal dan waktu yang banyak. (2) Pada saat video ditayangkan, gambar dan suara akan berjalan terus sehingga tidak semua siswa mampu mengikuti informasi yang ingin disampaikan dari tayangan tersebut. (3) Diperlukan alat penunjang lain dalam penggunaannya, seperti Personal Computer atau laptop, LCD Proyektor dan perangkat audio yang memadai.

\section{SIMPULAN}

Pengembangan media audiovisual untuk pembelajaran memperbaiki motor listrik di SMK telah dikembangkan berdasarkan lima tahap atau langkah utama sederhana yaitu tahap analisis kebutuhan, tahap desain produk, tahap pembuatan produk (produksi), tahap validasi, dan tahap uji coba. Setelah dilakukan proses penyempurnaan berdasarkan data yang diperoleh dari proses validasi dan uji coba lapangan, maka hasil pengembangan media ini dapat disimpulkan sebagai berikut:

1. Media audiovisual untuk pembelajaran memperbaiki motor listrik di SMK telah dikembangkan di SMK Negeri 1 Sarolangun berdasarkan hasil analisis, tujuan pembelajaran, dan standar kompetensi memperbaiki motor listrik.

2. Berdasarkan hasil uji coba lapangan media audiovisual untuk pembelajaran memperbaiki motor listrik di SMK ini menarik, efektif dan dapat meningkatkan hasil belajar siswa.

\section{DAFTAR PUSTAKA}

Arsyad, A. 2011. Media Pembelajaran, Jakarta: PT. Raja Grafindo Persada.

Asyhar, R. 2010. Kreatif Mengembangkan Media Pembelajaran. Jakarta: Gaung Persada.

Borg, Walter R, dan Meredith D. Gall. 1983. Educational Research An Introduction. New York: Longman.

Dick, W. \& Carey. 2005. The Systematic Design of Instruction Sixth Edition. Boston: Pearson.

Direktorat Pendidikan Menengah Kejuruan. 2004. Kurikulum SMK Edisi 2004 Jakarta: Direktorat Jenderal Pendidikan Dasar dan Menengah Departemen Pendidikan Nasional Republik Indonesia.

Hanafiah, N. dan Suhana, C. 2009. Konsep Strategi Pembelajaran. Bandung: Refika Aditama.

Mayer, R.E. 2009. Multimedia Learning, Prinsip-prinsip dan Aplikasi. Terjemahan Teguh Wahyu Utomo. Yogyakarta: Pustaka Pelajar.

Sadiman, A.S, Rahardjo, R, Haryono, A, Rahardjito. 2009. Media Pendidikan, Pengertian, Pengembangan, dan Pemanfaatannya. Jakarta: PT Rajawali Grafindo Persada.

Sidi, I.D. 2004. Kurikulum SMK Edisi 2004. Jakarta: Direktorat Jenderal Pendidikan Dasar dan Menengah Departemen Pendidikan Nasional Republik Indonesia.

Trianto. 2007. Model Pembelajaran Terpadu Dalam Teori dan Praktik. Jakarta: Prestasi Pustaka.

Undang-Undang RI. No. 20 Tahun 2003 Tentang Sistem Pendidikan Nasional. Jakarta: Cemerlang.

Wena, M. 2010. Strategi Pembelajaran Inovatif Kontemporer. Jakarta: Bumi Aksara. 